\title{
BUSINESS CAPABILITIES AND HR KNOWLEDGE’ AS THE CRITICAL FACTOR OF DUE DILIGENCE IN PRE-ACQUISITION PHASE
}

\author{
Alen Sacek ${ }^{1}$, Baiba Šavriṇa ${ }^{2}$
}

\begin{abstract}
Previous theoretical research has argued that due diligence in the pre-acquisition phase is traditionally oriented towards legal and financial matters. However, in the innovation-driven market environment, where firms need to maintain competitive strength, business skills and knowledge play important roles. Despite this difference, the due diligence research continues in traditional areas, e.g., financial history, legal and commercial liabilities, and tax issues. Hence, the problem may arise in acquirers overpaying or mistakenly rejecting a target firm. There is a need for assessing 'Business Capabilities and Human Resources Knowledge' for due diligence in the pre-acquisition phase. Based on a fundamental review of critical factors in mergers and acquisitions, this study seeks to examine the inclusion of this factor in due diligence during pre-acquisition. The research method includes a cross-sectional survey among firms with cross-border acquisition experience. The results of the empirical research provide reasonable support towards the organizational learning theory, suggesting that the more the acquirer learns about the critical factor, "Business Capabilities and Human Resources Knowledge", the better the acquisition success. These results highlight the importance of expanding the traditional due diligence view by including this critical factor as the integral part of the pre-acquisition investigation.
\end{abstract}

JEL Classification Number: G23, G34, DOI: http://dx.doi.org/10.12955/cbup.v4.757

Keywords: Business capabilities, cross-border, due diligence, acquisition, acquisition premium, synergy effects.

\section{Introduction}

The waves of mergers and acquisitions has increased since the late 1990s and early 2000s, especially in terms of cross-border acquisitions. Cross-border acquisitions concentrate on sectors with intensified global competition and market pressures of falling commodity prices, excess capacity, and rapid technological change. At the firm level, competitive advantage arises from the existence of firmspecific intangible assets (e.g., production knowledge, employee skills, and management competence). This has been enhanced by the rapid technological advances and growing knowledge intensification in the industries. Firms have supplemented organic growth by acquiring specific knowledge and business capabilities to accelerate the pace of innovation and maintain or develop a new competitive advantage (Makri, Hitt \& Lane 2010). While the outcome of such endeavors is covered by the academic research, the assessment of this risky undertaking, prior to signing an acquisition contract, is not often performed. Past research has focused more on integration during the post-acquisition phase for the factors for crucial success (Hitt et al., 2009). However, integration is heavily bound to a set of resources being sought in the acquisition. This research aims to describe an issue that, until now, has received little attention in the literature, namely, the effects of 'Business Capabilities and Human Resources Knowledge' in cross-border acquisitions.

\section{Review of the Academic Research}

According to King et al. (2004), operating synergies allow firms to increase their operational efficiency and their operating income from existing assets, increased growth, or both. As these impact margins, returns, and growth, they impact the value of the firms involved in the acquisition.

The critical factors determine success or failure of business, or in the context of this research, the cross-border acquisition results (Tewes, 2001). The acquirer must have a clear picture of their own strengths and weaknesses and consider opportunities and threats the acquisition might bring (Gomes et al., 2013, p. 19). Typical motives of cross-border acquisitions are potential synergies and acquisition of special knowledge and skills to enhance competitiveness in the industry. Hitt et al. (2009) argued that innovation had become an increasingly important determinant of value creation in many industries. Furthermore, acquiring existing foreign business expanded their own set of resources in knowledge base, human resources, business capabilities, and an established market access and reputation (Firstbrook, 2008, p. 54; Shimizu et al., 2004, p. 311; Cullinan et al., 2002, p. 5). Such

\footnotetext{
${ }^{1}$ Alen Sacek, University of Latvia, Riga, Latvia, alen.sacek@gmail.com

${ }^{2}$ Baiba Šavriņa, University of Latvia, Riga, Latvia
} 
resources strengthen an acquirer's endowment, are complementary, and enable leverage of existing resources (Phene et al., 2010, p. 757). The problem lies in the assessment of their potential, as the acquiring firm does not have full scope of the information necessary to determine the acquisition price or the suitability of the complementary resources the target may bring. This gap in information status is the information asymmetry problem. Strategic management researchers use these insights to understand the reasons for failure in the mergers and acquisitions and to identify ways that managers can cope with the challenges presented by the difference in knowledge between acquirer and seller (Reuer, 2005, p. 15). Acquirers identify and evaluate acquisition targets on the basis of their existing knowledge and the information they gain through different contexts for searching information, such as, thorough a risk assessment during the pre-acquisition phase. Implicitly, information asymmetry carries the risk of improperly evaluating assets, leading to an overpayment (Mukherji et al., 2013, p. 40).

In the acquisition, the acquirer and the seller have different information bases, which may partially explain incorrect evaluations. A detailed investigation during the pre-acquisition phase creates an adequate information basis and supports decision-making, avoiding possible overpayment. The investigation needs to extend to identifying the domains of information required to achieve an informed acquisition. This process mostly conforms to the exploratory learnings (Barkema \& Schijven, 2008; Collins et al., 2009; Very \& Schweiger, 2001). The exploratory nature of such learnings ensures that all major information is evaluated during the pre-acquisition.

The main reason for failure in cross-border acquisitions is an improper acquisition price and unrealized potential for synergy (Hitt et al., 2009, Collins et al., 2009). When valuing the target firm, the acquiring companies often rely on market-based price measures, which reflect the acquisition prices of recent comparable transactions, neglecting the potential value for the specific buyer. Malhotra and Zhu (2013, p. 272) indicated that the theoretical perspectives of an acquisition premium mostly rely on synergies, bargaining power, managerial hubris, or information asymmetry. The main conclusion of their studies, however, show the acquirers are oriented by comparable acquisitions rather than by detailed investigation of critical factors during pre-acquisition. Hence, to avoid such overpayments and the devaluing of target firms, adequate evaluation, based on reliable and complete information is needed during the pre-acquisition phase. Such an investigation is due diligence, where the information is mainly based on publicly available data and external expert interviews (Adolph et al., 2006, Brauer, 2006, p. 775). Due diligence comprises a detailed investigation and risk assessment of a wide area of the targets specifications, either quantifiable or non-quantifiable (Angwin, 2001, p. 33; Hopkins, 1999, p. 233; Knecht \& Calenbuhr, 2007, p. 425). Diligence can require assessing the competitive strength of the target, the critical capabilities, resources needed to be retained, and the operating models to be adopted across the whole organization. As the transfer of business capabilities and knowledge enriches an acquirer's value chain, these factors need to be adequately assessed. The review of the potential for synergies and the expected cost is the core task in due diligence, which is considered the most important motive for the intended acquisition (Hopkins, 1999, p. 212).

\section{Components of the Critical Factor Business Capabilities and Human Resources Knowledge}

This research focused on the business capabilities and human resources knowledge, and this involved determining the components. Traditionally, due diligence does not usually consider the employee's skills and knowledge in an evaluation. However, in a risk-oriented environment, the acquirer understands the risk associated with the value of the acquisition decreasing when productive employees leave or where knowledge resources are not identified and evaluated. Hence, the primary research task was to assess the influential factors from the perspective of the acquiring firm. Furthermore, the influential factors required extensive investigation during the pre-acquisition phase. A detailed evaluation of technological competence, as a complementary resource for creating value in the success of subsequent acquisitions, was based on the absorptive capacity. The more similar the technological knowledge, the more productive is the assimilation and commercial exploitation of the acquired firm's knowledge (Makri et al., 2010).

In terms of human resources and workforce capabilities (operational level), research has shown that it is essential to consider such factors because of their strong influence on the success of a transaction (Schuler \& Jackson, 2001, p. 243; Perry \& Herd, 2004, p. 13). The firm's value of the target company 
is tied to intangible assets, which include human resources and specific knowledge of skilled people. The main factors regarding human resource knowledge are the capabilities of the workforce and management that lead ambitious projects. High numbers of acquisitions have failed because an acquirer neglected to identify the risk involved with integrating a target that had dissimilar management skills or operational processes (Perry \& Herd, 2004, p. 13). Management capabilities have significant effects on the integration of the acquired unit, and these need to be involved in forming and implementing the integration (Kissin \& Herrera, 1990, p. 4; Perry \& Herd, 2004, p. 18). During the acquisition phase, managers communicate and motivate employees and stakeholders regarding the planned acquisition. Also in the post-acquisition phase, the role of the managers is most necessary, because the turnover rate of key employees is a frequent problem, resulting in a poor acquisition (Krug 2009, p. 34; Harding et al. 2007, p. 125). The due diligence phase is the time to assess the management potential and commitment in the target firm (Marks \& Mirvis 2001, p. 90). The capabilities on an operational level that will be needed in the future to complement products and services or create synergies and values need to be identified through a detailed risk assessment (Price et al. 1998, p. 22). Especially, firms with plans for acquiring capabilities for innovation are interested in identifying and retaining intellectual capital and knowledge (Lemieux \& Banks 2007, p. 1413). Knowledge is considered the most strategically significant resource in the organization. Knowledge management and merger acquisitions are related in transforming companies through organizational change and acquisitions. The combined knowledge creates synergies and allows the new organization to gain a further competitive advantage. Thus, the acquirer's ability to create and utilize knowledge efficiently and effectively is crucial (Lemieux \& Banks 2007, p. 1416). Porrini (2004) argued that, by knowing how knowledge can be shared within the organization, an acquirer is able to use such insight in decisions required of the pre-acquisition phase. By conducting a 'knowledge due diligence', the acquiring firm can determine the potential for sharing knowledge with the target firm. 'Knowledge due diligence' refers to assessing whether combining the firms will enable the sharing of knowledge between them, with the acquisition creating synergies and increase efficiencies. The pre-assessment to identify insufficiencies in the target's capabilities and the potential for leverage is a part of 'improved due diligence' (Perry \& Herd 2004, p. 13). Accordingly, the crucial task is the evaluation of the adaptation and leverage of complementary businesses and their management capabilities to achieve operational synergy. In summarizing, 'Business Capabilities and Human Resources Knowledge', as the critical factor of pre-acquisition due diligence, has four components:

1. Business capabilities are distinct competencies that work together in a system and are organized to support a company's strategy, integrate different human resource profiles, processes, and technologies;

2. Technological competence includes the technological knowledge embodied in products, processes, and knowledge of the workforce to deliver inventions;

3. Management competence include the managerial skills within the firm to efficiently use the firm's resources; and

4. Workforce capabilities are connected to industry specific education and the working experience of the operational and management personnel. This builds the ground for successful realization of technological knowledge and combined synergies.

Approaches for measuring the acquisition success vary between subjective (qualitative assessments for synergy realization) and objective measurements (accounting and financial performance). Schoenberg (2004) clearly stated that use of expert informants for a subjective assessment is suitable when multiple measures of acquisition success have been considered. This study's questionnaire included six questions about performance and six about meeting expectations. The results were weighted according to the acquirer's attributed importance. In this research, the acquisition success was based on degree of synergy (Schoenberg, 2004) in terms of research and development, service and manufacturing, and asset utilization. The research hypothesis is that pre-acquisition due diligence positively influences cross-border acquisition success and the four critical factors: business capabilities, technological competence, management capabilities, and workforce capabilities and human resource (HR) knowledge, in due diligence during the pre-acquisition phase. The research framework scheme is summarized in Figure 1. 
Figure 1: Model of business capabilities and acquisition success (operational synergy effects)

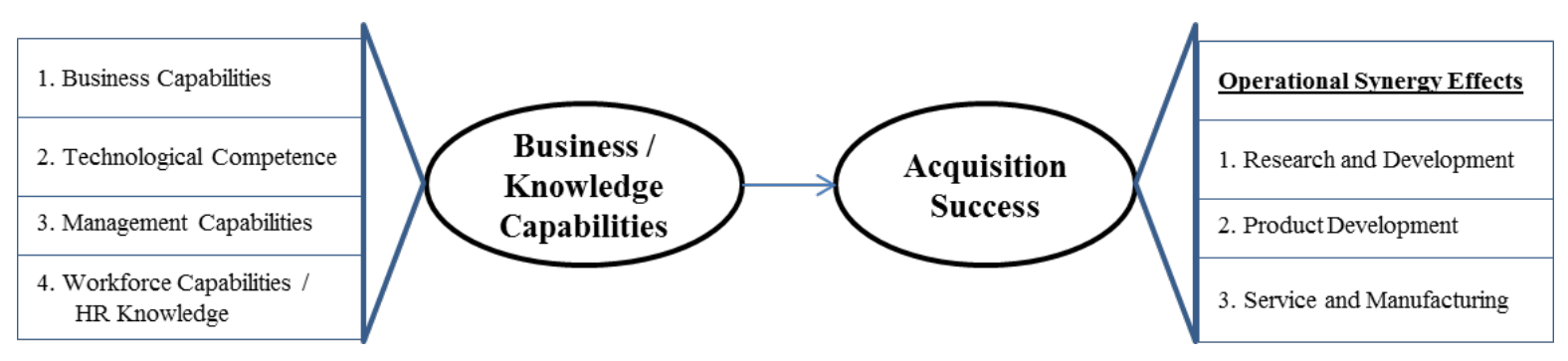

Source: Author

In addition, these research results were compared to secondary retrieved data of goodwill impairment, which served as a dependent variable. Goodwill impairment arises when the price paid for a target firm exceeds the fair value of the firm's net assets, which the acquirer recognizes from its consolidated financial statements. A cause of goodwill impairment is overpayment at the time of the original acquisition. Connected to the due diligence during the pre-acquisition phase, it may exist as a certain relationship of the firm's due diligence intensity and the subsequent value of the acquired companies. Consequently, goodwill assessment is an appropriate approach when the question arises as to whether the acquisition has been successful or not.

\section{Research Methodology}

A detailed questionnaire was designed and sent to firms involved in cross-border acquisitions. The data collection followed the method of judgement sampling, as accessing the data in the mergers and acquisitions industry was difficult because of confidentiality (Appelbaum et al. 2009, p. 42). Data were based on the experience of cross-border acquisitions of German automotive firms in the European market. The population consisted of members of the German Association of Automotive Industry (GAAI), which comprised automobile and other vehicle manufacturers, systems and module suppliers, and other car part manufacturers. Approximately 80 per cent of the GAAI members were medium-sized companies, based on the number of employees (above 250 employees). A defined criterion or the acquisition was acquiring more than 50 per cent of the firm, as this ratio leads to full control and consolidation within the financial accounts of the acquirer. The considered time-frame was from 2006 to 2013. The total acquisition volume was $€ 41.2$ bn (378 acquisitions), of which $€ 15.9$ bn involved the 85 acquisitions that were included in the present survey. The sample population was derived and tested for bias and other inconsistencies. In addition to comparing the models of primary and secondary data, to reduce bias, incorporating the methods from Podsakoff et al. (2003) and MacKenzie and Podsakoff (2012, p. 549), this study performed the following procedural remedies:

1. The questionnaire included questions that were thematically separated into independent variables (critical factors) and a dependent variable (acquisition success) in the survey instrument;

2. The statistical test, Harman's single factor, was used to validate the absence of bias;

3. A non-response bias was investigated by comparing respondents with non-respondents, directly along the dimensions of relative acquisition size (number of employees) and acquisition experience. The non-respondents had either low acquisition volume or no acquisition experience, so that the inclusion of other firms would not change research results.

With these measures, the sample was deemed representative and not biased, and that it was appropriate for testing the model on critical factors in due diligence during the pre-acquisition phase of cross-border acquisitions.

The research was based on a cause-and-effect relationship, whereby the measures in the preacquisitions phase were connected with the post-acquisition success using univariate and multiple regression analyses according to the criteria for quantitative research in social science, and relying on the methods of Crown (1998) and Backhaus et al. (2003). Primary data were supported by secondary data in a separate model. The secondary data regarding goodwill were retrieved from annual company 
statements. Specifically, a correlation analysis of the model variables and regression analyses with on the data for a quantitative analysis of critical factor business capabilities for due diligence during preacquisition.

\section{Results and Discussion}

The dependent variable presented a Cronbach's Alpha of 0.91, which indicated high reliability. The measurement of the reliability of the categories used as independent variables, the Cronbach's Alpha, was calculated to indicate the acceptable level of reliability. For the decision of further testing, the data were checked for abnormalities and possible suitability of regression analysis. The correlation matrix indicated moderate correlations rather than strong correlations (Table 1).

The Pearson's $r$ for the correlation between the model variables was above 50 per cent, indicating a positive relationship between all included variables. The correlation between the independent variables and the acquisition success was strong for technological competence and the business capabilities, indicating that changes in these variables were strongly correlated with changes in the acquisition success. The results of the correlation analysis indicated that the explanatory variables had a strong relationship with acquisition success.

Table 1: Correlation analysis of the model variables, calculations based on survey results $(n=85)$

\begin{tabular}{|c|c|c|c|c|c|}
\hline Sig. 2-tailed Test & $\begin{array}{c}\text { Business } \\
\text { Capabilities }\end{array}$ & $\begin{array}{l}\text { Management } \\
\text { Competence }\end{array}$ & $\begin{array}{c}\text { Workforce } \\
\text { Capability } \\
\text { / HR } \\
\text { Factor }\end{array}$ & $\begin{array}{l}\text { Technological } \\
\text { Competence }\end{array}$ & $\begin{array}{c}\text { Synergy } \\
\text { Level } \\
\text { Success }\end{array}$ \\
\hline \multirow{3}{*}{$\begin{array}{l}\text { Business } \\
\text { Capabilities }\end{array}$} & 1 & $0.654^{* *}$ & $0.512^{* *}$ & $0.707^{* *}$ & $0.725^{* *}$ \\
\hline & & 0.000 & 0.000 & 0.000 & 0.000 \\
\hline & 85 & 85 & 85 & 85 & 85 \\
\hline \multirow{3}{*}{$\begin{array}{l}\text { Management } \\
\text { Competence }\end{array}$} & $0.654^{* *}$ & 1 & $0.517^{* *}$ & $0.567^{* *}$ & $0.590^{* *}$ \\
\hline & 0.000 & & 0.000 & 0.000 & 0.000 \\
\hline & 85 & 85 & 85 & 85 & 85 \\
\hline \multirow{3}{*}{$\begin{array}{l}\text { Workforce } \\
\text { Capability / } \\
\text { Human } \\
\text { Resources } \\
\text { Factor }\end{array}$} & $0.512^{* *}$ & $0.517^{* *}$ & 1 & $0.504^{* *}$ & $0.560^{* *}$ \\
\hline & 0.000 & 0.000 & & 0.000 & 0.000 \\
\hline & 85 & 85 & 85 & 85 & 85 \\
\hline \multirow{3}{*}{$\begin{array}{l}\text { Technological } \\
\text { Competence }\end{array}$} & $0.707^{* *}$ & $0.567^{* *}$ & $0.504^{* *}$ & 1 & $0.888^{* *}$ \\
\hline & 0.000 & 0.000 & 0.000 & & 0.000 \\
\hline & 85 & 85 & 85 & 85 & 85 \\
\hline \multirow{3}{*}{$\begin{array}{l}\text { Synergy Level } \\
\text { Success }\end{array}$} & $0.725^{* *}$ & $0.590^{* *}$ & $0.560^{* *}$ & $0.888^{* *}$ & 1 \\
\hline & 0.000 & 0.000 & 0.000 & 0.000 & \\
\hline & 85 & 85 & 85 & 85 & 85 \\
\hline
\end{tabular}

Table 2: Model summary, calculations based on survey results $(n=85)$

\begin{tabular}{|l|r|r|r|}
\hline & \multicolumn{1}{|c|}{ Estimate } & \multicolumn{1}{c|}{ p-value } & \multicolumn{1}{c|}{ VIF } \\
\hline (Intercept) & 0.262 & 0.552 & \\
\hline Business Capabilities and HR Knowledge & 0.865 & 0.000 & 1.9 \\
\hline
\end{tabular}

Adjusted r-squared: 0.4642 , F-statistic: 73.78 on 1 and 83 DF, p-value: 0.000

HR: human resource; VIF: variance inflation factors

Source: Author 
To measure the predictive capability, a regression analysis was performed. The results of the regression model are shown in Table 2.

There was a positive relationship between the critical factors in due diligence, the business capabilities and HR knowledge, and the acquisition success in cross-border acquisition. The significance score (pvalue $<0.000$ ) indicated the relationship was significant, with acquisition success being attributed to the critical factor 'Business Capabilities and HR Knowledge'. As usual for linear regression models using one independent variable, the p-value for its coefficient corresponded to the F-statistics. The predictive influence was strong as increasing 'Business Capabilities and HR Knowledge' led to a 0.865-unit enhancement in acquisition success. According to the model's strength, the F-statistic was above the critical value (confidence level 0.999) in all four regressions. It can be supposed that the models, as a whole, predict the dependent variable. In terms of explanatory power, the r-squared statistic of 0.4642 indicated that the model's overall power and the extent to which the variables in the model explained the variation of the dependent variable acquisition success was high. Overall, the results of the regression analysis supported those of the correlation analysis that focused on the joint effects.

To match the research results with secondary data, determinants of the firms' goodwill impairment were estimated by linear logistical regression. Table 3 shows the test results, with a differing dependent variable, i.e., the impact of goodwill impairment of the acquired firm.

Table 3: Model with use of secondary data (logistical regression analysis), calculations based on survey results $(\mathrm{n}=85)$

\begin{tabular}{|l|r|r|r|}
\hline & Estimate & p-value & \multicolumn{1}{|c|}{ VIF } \\
\hline (Intercept) & -11.576 & 0.149 & \\
\hline Business Capabilities and HR Knowledge & 3.353 & 0.018 & 1.9 \\
\hline \multicolumn{4}{|c|}{ Pseudo-adjusted r-squared: 0.6109; F-statistic: not applicable } \\
\hline
\end{tabular}

The criteria were rated by 'Yes' or 'No', with the variable equaling one for 'Yes', when the goodwill was impaired or the firm had been sold within the given period, and a zero for "No". The critical factor variables remained the same. Table 3 shows the adjusted r-squared, explaining 61 per cent of the dependent variable variation. The high adjusted $r$-squared with 'Business Capabilities and HR Knowledge' and 'Goodwill Impairment' indicated highly predictive powers, supporting the research results from the primary data analyses.

The hypothesis was that "Business Capabilities and HR Knowledge" was a critical factor in due diligence during the pre-acquisition phase. This critical factor was shown to relate the acquisition success, which was measured on individual and joint effects by using primary and secondary research data. The individual components were operational business capabilities, technological competence, and workforce capabilities and human resource knowledge. The skills of business and technological capabilities of the workforce, which are crucial elements for clear focus to continue in realizing synergies of operations in the value chain of the automotive industry. The acquiring firm needs to prove the suitability of the target firm's intangible resources. Laabs et al. (2011, p. 86) and Laabs and Schiereck (2008) showed that lack of experience in evaluating such skills will negatively impact longterm acquisition success, confirming the relevance of this critical factor. The importance of employee capabilities and business capabilities as critical factors, contributing to acquisition success, were confirmed, concurring with findings of prior research (e.g., Shimizu et al. 2004; Perry \& Hard 2004; Harding \& Rouse 2007; Krug 2009). The high significance of human resource knowledge conforms to prior research findings regarding firms that acquired capabilities for innovation and human capital (Lemieux \& Banks 2007, p. 1413). In concluding, the results of this research conform to specific research results relating to the automotive industry.

\section{Conclusion}

The research provided empirical support for the notion that the business capabilities and HR knowledge are critical factors in the due diligence during pre-acquisition. The hypothesis was supported, in that 'Business Capabilities and Human Resources Knowledge', consisting of four 
explanatory variables (management competence, technological competence, workforce capabilities, and business capabilities) enhanced the success in cross-border acquisitions. The results also indicated that such critical factors have significant effect on acquisition success relating to the degree of operational synergies. These two areas create the main asset in the realization of synergy values in the post-acquisition phase.

This finding has certain implications for future research on acquisitions. It suggests that research related to cross-border acquisitions should take a broader look at the factors that influence postacquisition success. This study's research results reveal the necessity for including the critical factor 'Business Capabilities and Human Resources Knowledge' in the pre-acquisition phase for due diligence. In this context, during pre-acquisition, including factors of business capabilities and human resources knowledge in due diligence should be integral for each acquiring firm to avoid overpaying the target firm or declining the acquisition of a suitable firm due to an undiscovered potential for synergy.

The findings provide reasonable support for the underlying exploratory learning theory, that acquiring target specific knowledge helps to balance information asymmetry. The inclusion of the secondary data for goodwill impairment reflected the positive relationship of the goodwill impairment and the pre-acquisition assessment of the business capabilities and HR knowledge.

The research results showed that the more information the acquiring firm obtains on 'Business Capabilities and Human Resources Knowledge', the more it learns about the target firm and decreases the likelihood of information asymmetry. The learning occurs through assessing critical factors in the due diligence undertaken during the pre-acquisition phase. The results of the due diligence must be part of the planning for determining an achievable degree of synergies. The findings on due diligence and the potential for synergies should create the basis for a fair bidding price by the acquirer or alternately, lead to rejecting the acquisition.

\section{References}

Adolph, G., Gillies, S., \& Krings, J., (2006). Strategic Due Diligence: A Foundation for M\&A Success. Strategy + Business enews, pp.1-8.

Angwin, D., (2001). Mergers and Acquisitions across European Borders: Preacquisition Due Diligence and the Use of Professional Advisers. Journal of World Business, 36(1), pp.32-57.

Appelbaum, S. H., Roberts, J. \& Shapiro, B. T., (2009). Cultural Strategies in M \& As: Investigating Ten Case Studies. Journal of Executive Education, 8(1), pp.33-58.

Backhaus, K., Erichson, B., Plinke, W., \& Weiber, R. (2003). Multivariate Analysemethoden 10th ed., Berlin: Springer Verlag.

Barkema, H. G. \& Schijven, M. (2008). The pre-acquisition evaluation of target firms and cross border acquisition performance. Journal of Management, 34(3), pp.594-634.

Brauer, M. (2006). What Have We Acquired and What Should We Acquire in Divestiture Research? A Review and Research Agenda. Journal of Management, 32(6), pp.751-785.

Collins, J. D., Holcomb T., Certo, T., Hitt, M. A., \& Lester, R. H. (2009). Learning by Doing: Cross-border Mergers and Acquisitions. Journal of Business Research, 62 (12), pp. 1329-1334.

Cullinan, G., \& Holland, T., (2002). Strategic Due Diligence. In Due Diligence for Global Deal Making. 2002, Rosenbloom, A., Bloomberg Press Princeton, pp. 13-50.

Crown, W. H. (1998). Statistical Methods for Social and Behavioral Sciences - Multiple Regression and Limited-DependentVariable Models 1st ed., Westport, Connecticut: Praeger Edition.

Firstbrook, B. C., (2008). Cross-border M \& A Handle with care. Accenture Outlook 2008, (3), p. 10. London.

Gomes, E., Angwin, D. N., Weber, Y., \& Tarba, S. Y., (2013). Critical Success Factors through the Mergers and Acquisitions Process: Revealing Pre- and Post-M \& A Connections for Improved Performance. Thunderbird International Business Review, 55(1), pp.13-35.

Harding, D., \& Rouse, T. (2007). Human Due Diligence. Harvard business review, 85(4), pp.124-131.

Hitt, M. A., King, D., Krishnan, H., Makri, M., \& Schijven, M. (2009). Mergers and acquisitions: Overcoming pitfalls, building synergy, and creating value. Business Horizons, 52(6), pp.523-529.

Hopkins, H. D. (1999). Cross-border Mergers and Acquisitions: Global and Regional Perspectives. Journal of International Management, 5(3), pp.207-239.

King, D. R., Dalton, D. R., Daily, C. M., \& Covin, J. G. (2004). Meta-analyses of post-acquisition performance: indications of unidentified moderators. Strategic Management Journal, 25(2), pp.187-200. 
Kissin, W. D., \& Herrera, J. (1990). International Mergers and Acquisitions. The Journal of Business Strategy, 11(July/August), pp.51-54.

Knecht, F., \& Calenbuhr, V. (2007). Using capital transaction due diligence to demonstrate CSR assessment in practice. Corporate Governance, 7(4), pp.423-433.

Krug, J. A. (2009). Brain drain: why top management bolts after M\&As. Journal of Business Strategy, 30(6), pp.4-14.

Laabs, J., Schiereck, D., Babl, C. (2011). How a Good Bidder Becomes a Good Target: The Case of Continental AG Acquiring Siemens VDO. International Review of Economics \& Management Engineering, 1(1), pp.7-21.

Laabs, J. P., Schiereck, D. (2008). The long-term success of M\&A in the automotive supply industry: determinants of capital market performance. Journal of Economics and Finance, 34(1), pp.61-88.

Lemieux, O. P., Banks, J. C. (2007). High tech M\&A - strategic valuation. Management Decision, 45(9), pp.1412-1425.

MacKenzie, S. B., Podsakoff, P. M. (2012). Common Method Bias in Marketing: Causes, Mechanisms, and Procedural Remedies. Journal of Retailing, 88(4), pp.542-555.

Malhotra, S., Zhu, P. (2013.) Paying for cross-border acquisitions: The impact of prior acquirers ' decisions. Journal of World Business, 48(2), pp.271-281.

Makri, M., Hitt, M., Lane, P. (2010). Complementary Technologies, Knowledge Relatedness and Innovation in High Technology Mergers and Acquisitions. Strategic Management Journal, 31 (6), pp. 602-628.

Marks, M., Mirvis, P. H. (2001). Making Mergers and Acquisitions Work: Strategic and Psychological Preparation. Academy of Management, 15(2), pp.80-92.

Mukherji, A., Mukherjia, J., Dibrell, C., Francisco, J. D. (2013). Overbidding in cross-border acquisitions: Misperceptions in assessing and valuing knowledge. Journal of World Business, 48(1), pp.39-46.

Perry, J. S. \& Herd, T. J. (2004). Mergers and Acquisitions: Reducing M\&A risk through improved due diligence. Strategy \& Leadership, 32(2), pp.12-19.

Phene, A., Tallman, S., Almeida, P. (2010). When Do Acquisitions Facilitate Technological Exploration and Exploitation? Journal of Management, 38(3), pp.753-783.

Podsakoff, P. M., MacKenzie, S. B., Lee, J. (2003). Common Method Biases in Behavioral Research: A Critical Review of the Literature and Recommended Remedies. Journal of Applied Psychology, 88(5), pp.879-903.

Porrini, P. (2004). Can a Previous Alliance Between an Acquirer and a Target Affect Acquisition Performance? Journal of Management, 30(4), pp.545-562.

Price, M., Harvey, M., Lusch, R. F. (1998). Beyond traditional due diligence for mergers an acquisitions in the 21st century. Review of Business, 19(3), pp.17-22.

Reuer, J. J. (2005). Avoiding Lemons in M \& A Deals. MIT Sloan Management Review, 46(3), pp.14-17.

Schoenberg, R. (2004). Dimensions of Management Style Compatibility and Cross-Border Acquisition Outcome. Advances in Mergers and Acquisitions, 3(04), pp.149-175.

Schuler, R. \& Jackson, S. (2001). HR Issues and Activities in Mergers and Acquisitions. European Management Journal, 19(3), pp.239-253.

Shimizu, K., Hitt, M. A., Vaidyanath, D., Pisano, V. (2004). Theoretical foundations of cross-border mergers and acquisitions: A review of current research and recommendations for the future. Journal of International Management, 10(3), pp.307-353.

Tewes, C. (2001). M\&A Privatisations in Poland - Key Success Factors of Cross-border Acquisitions into the Polish Market. Dissertation. p. 235.

Very, P., Schweiger, D. M. (2001). The Acquisition Process as a Learning Process: Evidence from a Study of Critical Problems and Solutions In Domestic and Cross-Border. Journal of World Business, 36(1), pp.11-31. 